\title{
WAŻNIEJSZE METODY POMIARU GLOBALIZACJI I INTERNACJONALIZACJI PRZEDSIĘBIORSTW
}

Z a r y s t r e ś c i: Globalizacja to proces scalania gospodarek narodowych, przejawiający się w dynamicznym wzroście obrotów handlowych, przepływów kapitałowych i usługowych w ujęciu międzynarodowym oraz będący rezultatem postrzegania całego świata jako rynku zbytu. Internacjonalizacja odnosi się w teorii i praktyce do określania poziomu umiędzynarodowienia przedsiębiorstw. We współczesnej gospodarce ważne jest zatem wskazanie nie tylko na formę internacjonalizacji przedsiębiorstw, ale również określenie wskaźnika ich umiędzynarodowienia.

S ł o w a k l u c z o w e: metody pomiaru; globalizacja; internacjonalizacja przedsiębiorstw.

Klasyfikacja JEL: F60.

\section{WSTĘP}

W dzisiejszych czasach coraz częściej zaczynają dominować takie terminy, jak globalizacja, internacjonalizacja przedsiębiorstw, przemieszczanie się czy otwieranie się zagranicznych rynków. Postępująca internacjonalizacja i globalizacja gospodarki światowej, ujmowana jako nowy etap umiędzynarodowienia działalności gospodarczej, wpłynęła na intensyfikację powią-

* Adres do korespondencji: Robert Rogaczewski, ul. Przemysłowa 3C/30, 62-510 Konin, e-mail: r.rogaczewski@gmail.com. 
zań gospodarek narodowych i wzrost współzależności. Nie ulega wątpliwości, że poziom umiędzynarodowienia przedsiębiorstwa jest trudny do określenia. W literaturze przedmiotu można się spotkać przeważnie z próbą określenia tego poziomu z wykorzystaniem metod jakościowych. Jednakże istotnym kontrastem byłoby jego określenie $\mathrm{z}$ wykorzystaniem metod ilościowych.

Celem niniejszej publikacji jest przedstawienie ważniejszych metod pomiarowych internacjonalizacji i globalizacji. W tym celu dokonano szerokiej analizy literatury przedmiotu z zakresu internacjonalizacji i biznesu międzynarodowego.

\section{TEORETYCZNE ASPEKTY INTERNANCJINALIZACJI I GLOBALIZACJI}

Analiza literatury przedmiotu, zarówno rodzimej, jak i zagranicznej, pozwala na wyodrębnienie licznych ujęć znaczeniowych internacjonalizacji i globalizacji. Proces internacjonalizacji należy traktować jako długotrwałą i znaczącą dla przedsiębiorstwa działalność za granicą. Działalność ta może dotyczyć wysokiego udziału eksportu w obrocie całkowitym, jak i rozproszonej sieci inwestycji bezpośrednich we wszystkich regionach świata [Zur, Krystek, 1997, s. 5]. Internacjonalizacja to każdy rodzaj działalności gospodarczej podejmowanej przez przedsiębiorstwo za granicą [Rymarczyk, 2004, s. 19]. Dotyczy ona również zbudowania i realizacji transgranicznych usług, gdzie uzasadnienie ma związek pomiędzy wzrostem liczby przedsiębiorstw a liczbą konsumentów, których liczba rośnie wraz z otwieraniem się nowych rynków zagranicznych [Oesterle, 1999, s. 220]. Internacjonalizację należy traktować jako każdy rodzaj rozpoczęcia czynności transgranicznych przedsiębiorstwa, nie zważając na fakt, czy czynność takowa miała miejsce raz czy więcej [Dülfter, 1982, s. 50]. Konkurencja zagranicznych przedsiębiorstw na rynku krajowym jakiegoś przedsiębiorstwa krajowego sama w sobie jest internacjonalizacją [Perlitz, 2004, s. 9]. Analizując przedstawione wyżej rozważania dotyczące istoty internacjonalizacji, można bez wątpienia postrzegać ją dwuwymiarowo, tj. jako stan, który ma miejsce $\mathrm{w}$ określonym czasie ${ }^{1}$, oraz jako proces, który dotyczy zmian wraz z upływem czasu [Flaum, 1996, s. 11].

1 Do jego opisu używa się często pojęcia „umiędzynarodowienie”. 
Globalizacja postrzegana jest natomiast jako proces obejmujący wszystkie strefy społeczne państwa i obejmuje swoim zasięgiem instytucje międzynarodowe, stosunki między krajami w zakresie polityki i gospodarki, zmiany gospodarek narodowych i ich polityki wewnętrznej [Żurkowska, 2001, s. 150]. Obecnie określa się ją jako proces wzrostu współzależności ekonomicznych dzięki gwałtownemu rozwojowi międzynarodowej wymiany handlowej i kulturowej. Ekonomiczna interpretacja globalizacji dotyczy najczęściej działalności gospodarczej, gospodarki, rynków branżowych, przedsiębiorstw i otaczającej ich konkurencji. Globalizacja nie jest tylko pojęciem, za pomocą którego można dokonywać analizy wyłącznie zjawisk ekonomicznych zachodzących we współczesnej gospodarce światowej. Pod tym pojęciem rozumie się często określony stan gospodarki światowej, a więc liberalizację handlu i przepływ kapitału oraz narastające procesy integracji i internacjonalizacji [Gwiazda, 2000, s. 10]. Globalizacja dotyczy intensyfikowania przepływów kapitałowych, handlowych, usługowych i informacyjnych w skali świata, co prowadzi do scalania się gospodarek narodowych i tworzenia tzw. korporacji ponadnarodowych [Osiński, 2010, s. 34]. Przepływy te wywoływane są i stymulowane przez kraje najbardziej rozwinięte, jednakże nie odbywa się to bez udziału pozostałych uczestników rynku. W warunkach globalizacji na ,przetrwanie” mogą liczyć przede wszystkim ci, którzy budują właśnie transnarodowe korporacje [Ziółkowska, 2011, s. 227]. Ważnym aspektem w procesie globalizacji przedsiębiorstw jest analiza czynników, które mają bezpośredni wpływ na jego rozwój. Pojęcie ,globalizacji” analizowane jest zazwyczaj z ekonomicznego i politycznego punktu widzenia, w którym to przedstawia się pozytywne i negatywne oddziaływania. Wyróżnia się, oprócz politycznego i ekonomicznego wymiaru globalizacji, jej technologiczny, społeczny i kulturowy wymiar.

Warto również przytoczyć definicje wyżej wymienionych terminów według Dicken'a, który zwraca uwagę na zasadnicze różnice znaczeniowe. Według niego internacjonalizacja $\mathrm{w}$ ujęciu procesowym dotyczy rozszerzania działań gospodarczych ponad granicami państwa i w obrębie danego państwa. Procesy internacjonalizacji odzwierciedlają przemiany oraz zmiany ilościowe, które prowadzą do bardziej rozległej ekspansji geograficznej działalności gospodarczej. Procesy globalizacji dotyczą nie tylko geograficznego rozproszenia działalności gospodarczej, ale co ważniejsze, integracji działalności międzynarodowych. Odzwierciedlają one przede wszystkim zmiany jakościowe w sposobach organizacji działań gospodarczych [Dickens, 1998, s. 12]. 
Internacjonalizacja oznacza zatem rozszerzanie aktywności gospodarczych poza granice kraju. Ważnym aspektem internacjonalizacji jest obok importu i eksportu wejście na rynek zagraniczny. Globalizacja natomiast wychodzi poza zakres internacjonalizacji i uważana jest za wyższy etap umiędzynarodowienia, który traktuje świat jako jeden rynek [Rymarczyk, 2004, s. 19]. Jej znaczenie należy rozpatrywać w dwóch wymiarach, geograficznym i jakościowym. Pierwszy wymiar opisuje geograficzny zasięg aktywności międzynarodowych przedsiębiorstw w rozumieniu rosnącego, geograficznego podziału zakładów produkcyjnych oraz oddziałów. Wymiar jakościowy globalizacji oznacza intensywność powiązań w obszarze międzynarodowo rozproszonych zakładów produkcyjnych, oddziałów i logistyki w obrębie zintegrowanych łańcuchów dostaw. Wzmożona konkurencja pomiędzy międzynarodowymi przedsiębiorstwami a nowymi możliwościami optymalizacji łańcucha produkcyjnego i wartości zaliczają się również do tego wymiaru globalizacji. Ważne rolę w procesie internacjonalizacji i globalizacji odgrywa przedsiębiorstwo, które to poprzez sam fakt uczestnictwa $\mathrm{w}$ tym procesie staje się międzynarodowe.

\section{ZNACZENIE PRZEDSIĘBIORSTWA W PROCESIE INTERNACJONALIZACJ I GLOBALIZACJI}

Obok przedstawionego wcześniej procesowego postrzegania aktywności zagranicznych istnieje również instytucjonalna teoria, która łączy fenomen internacjonalizacji z danym przedsiębiorstwem. Dokonując analizy procesu internacjonalizacji i globalizacji, należy zwrócić uwagę na rolę przedsiębiorstwa, jaką odgrywa w gospodarce światowej. Przedsiębiorstwo staje się międzynarodowym w przypadku podejmowania aktywności za granicą. Ponieważ taki sposób postrzegania nie ma przyporządkowania do żadnego określonego obszaru funkcyjnego, klasyfikacja przedsiębiorstwa międzynarodowego zależna jest od rodzaju tych działalności zagranicznych [Perlitz, Schrank, 2013, s. 11]. Przedsiębiorstwa międzynarodowe podejmują transakcje z podmiotami gospodarczymi za granicą [Kutschker 1999a, s. 105] w dłuższym horyzoncie czasowym [Macharzina, 2003, s. 14]. Charakteryzują się one tym, że strategie przenoszone są ze spółki matki na spółki córki, centrala zaś rości sobie prawa do podejmowania decyzji. Celem tej koncepcji jest transfer wiedzy i Know-how na rynki zagraniczne, które w zakresie technologicznym i marketingowym są mniej rozwinięte aniżeli rynek krajowy. Istnieje 
również intensywna koordynacja i kontrola zagranicznych spółek córek poprzez spółkę matkę.

Z pojęciem ,przedsiębiorstwo międzynarodowe” wiążą się takie terminy, jak: przedsiębiorstwo multinarodowe, globalne czy transnarodowe.

Przedsiębiorstwo multinarodowe opisywane jest na podstawie portfolio narodowych jednostek, które cechuje strategiczna daleko idąca autonomia i które to pojawiają się jako rodzime przedsiębiorstwa na rynku. Centralnym zadaniem tych przedsiębiorstw jest zapewnienie dostępności produktów na ważnych z punktu widzenia przedsiębiorstwa rynkach oraz zwiększenie wydajności autonomicznych spółek córek [Welge, Holtbrügge, 2006, s. 48]. Warto zwrócić uwagę na kontrolę i koordynację realizowaną na podstawie osobistych kontaktów pomiędzy kierownictwem przedsiębiorstwa spółki matki a menedżerami spółek córek.

Analizując przedsiębiorstwa o charakterze globalnym, należy podkreślić, że ich nadrzędnym celem jest dążenie do coraz większej wydajności i w związku z tym wypracowanie głównych strategii. Ważnym aspektem przedsiębiorstwa globalnego jest tworzenie korzyści kosztowych poprzez scentralizowane, zorientowane na rynek światowy aktywności [Bartlett, Ghoshal, 1990a, s. 32]. Globalną koncepcję zarządzania przedsiębiorstwem charakteryzuje daleko idąca centralizacja majątku, zasobów przedsiębiorstwa i kompetencji oraz jednostronny przepływ dóbr, pracowników oraz Know-how z firmy matki do spółek córek.

Ostatnim typem przedsiębiorstwa jest przedsiębiorstwo transnarodowe, w ramach którego próbuje się połączyć globalną efektywność, lokalną umiejętność dopasowania się i zdolność uczenia się. Ten rodzaj przedsiębiorstw definiowany jest jako firmy działające w co najmniej dwóch krajach. Punktem docelowym ich działalności jest podejmowanie inwestycji bezpośrednich [Herkenrath, 2003, s. 19]. $\mathrm{KTN}^{2}$ jest przedsiębiorstwem mającym osobowość prawną, składającym się z firmy macierzystej i filii zagranicznych. Spółkom córkom przypadają zróżnicowane i wyspecjalizowane zadania, które mogą być wykonywane w różnych obszarach. Korporacje transnarodowe stanowią potężny i prężny krąg podmiotów w gospodarce i w wiodący sposób wpływają na przemiany zachodzące w świecie. Często ta grupa przedsiębiorstw współtworzy proces globalizacji i jest jedną z jego głównych sił napędowych. Przedsiębiorstwo macierzyste kontroluje aktywa przedsiębiorstw zagranicznych oraz zachowuje w stosunku do nich prawo do uczestniczenia w zarządzaniu. KTN uważane są jako charaktery-

2 Przedsiębiorstwo transnarodowe $=$ korporacja transnarodowa $(\mathrm{KTN})$ 
styczny element współczesnej gospodarki światowej oraz traktowane jako ważny kanał przepływu techniki i technologii do państw, w których tworzą swoje filie. Pozycja korporacji w gospodarce światowej ciągle wzrasta, zarówno pod względem ich liczby, zaangażowania kapitału za granicą, udziału w światowym produkcie brutto, eksporcie czy transferze technologii.

Wzrost aktywności zagranicznych poszczególnych przedsiębiorstw niesie ze sobą konieczność wypracowania odpowiedniej metody, której zastosowanie pozwoliłoby na określenie wskaźnika globalizacji i internacjonalizacji.

\section{WAŻNIEJSZE METODY POMIARU INTERNACJONALIZACJI I GLOBALIZACJI}

W świetle dotychczasowych rozważań o wpływie internacjonalizacji i globalizacji na gospodarkę światową warto zastanowić się nad metodami ich pomiaru. Z oczywistych względów miary globalizacji należy wykorzystywać w kontekście zmian, jakie zachodzą w otoczeniu kulturowym, społecznym, politycznym i ekonomicznym [Gołembska, 2014, s. 17]. Stopień internacjonalizacji przedsiębiorstw jest trudny do określenia, ponieważ nie wszystkie przedsiębiorstwa funkcjonują międzynarodowo $\mathrm{z}$ jednakową intensywnością. W literaturze przedmiotu spotkać się można z licznymi konceptami, które z jednej strony rozpatrują przedsiębiorstwo międzynarodowe, z drugiej zaś dokonują oceny internacjonalizacji tego przedsiębiorstwa. Proces internacjonalizacji i globalizacji przedsiębiorstwa międzynarodowego może być traktowany i analizowany w trzech płaszczyznach. Kutscher i Schmid wyróżniają [Kutschker, Schmid, 2008, s. 255]:

- metody ilościowe,

- metody jakościowe,

- metody integracyjne.

O ile problematyka jakościowych metod internacjonalizacji dotyczy jednowymiarowych i wielowymiarowych koncepcji internacjonalizacji przedsiębiorstw, i zaliczyć do nich należy przede wszystkim strategiczne orientacje Perlmutter'a oraz koncept Barlett/Ghoshal'a, o tyle ilościowe metody dotyczą zastosowania odpowiednich wskaźników matematycznych. W ramach metod ilościowych pomiaru internacjonalizacji i globalizacji należy wyróżnić ich dwa rodzaje, tj. jednowymiarowe i wielowymiarowe.

Jednowymiarowe koncepty pomiarowe ujmują stopień internacjonalizacji na podstawie jednego wskaźnika [Helmig i in., 2007, s. 87]. Wskaźni- 
ki te mogą dotyczyć wartości bezwzględnych (np.: liczba oddziałów zagranicznych, wielkość zapasów za granicą czy wielkość osiągniętych obrotów za granicą) oraz wartości względnych (np.: udział uzysku zagranicznego czy poziom zatrudnienia za granicą na tle ogółem). Jednowymiarowe metody pozwalające określić stopień internacjonalizacji posiadają zaletę, ponieważ do jego określenia potrzebne są wartości w ograniczonym zakresie i dostępne są one zazwyczaj w źródłach ogólnodostępnych [Fisch, Oesterle, 2003, s. 3]. Koncepty te są jednakże w znacznej mierze dotknięte błędami. Posługiwanie się różnymi wielkościami bazowymi może prowadzić do odmiennych, czasami sprzecznych określeń stopnia internacjonalizacji przedsiębiorstwa.

W przypadku wielowymiarowych konceptów stopień internacjonalizacji określany jest przy użyciu co najmniej dwóch wskaźników. Należy wyróżnić kilka metod pomiaru stopnia internacjonalizacji i globalizacji, które autor uznał za ważniejsze [Oesterle, Laudien, 2008, s. 27-36]:

- Transnationality Index UNCTAD

- stopień internacjonalizacji według Sullivan,

- stopień internacjonalizacji i globalizacji według Fisch/Osterle,

Transnationality Index [Nöcker, 2001, s. 11], jako jedna z metod, pozwala na określenie stopnia internacjonalizacji przedsiębiorstwa. Indeks ten powstał na podstawie UNCTAD, a jego celem jest określenie zaangażowania przedsiębiorstwa w gospodarce światowej. Składa on się z 3 wskaźników, pierwszy z nich dotyczy strony popytu, kolejne zaś podaży. Poniżej dokonano przyporządkowania poszczególnych zmiennych zarówno po stronie popytu, jak i podaży.

Tabela 1. Wskaźniki Transnationality Index

\begin{tabular}{|l|}
\hline \multicolumn{1}{|c|}{ Strona popytu } \\
\hline (1) Udział wielkości obrotu za granicą do całkowitego obrotu przedsiębiorstwa \\
\hline \multicolumn{1}{|c|}{ Strona podaży } \\
\hline (2) Udział wielkości majątku do całkowitego majątku przedsiębiorstwa \\
\hline (3) Udział liczby zatrudnionych za granicą do całkowitego zatrudnienia przedsiębiorstwa \\
\hline
\end{tabular}

Źródło: opracowanie własne na podstawie na podstawie: UNCTAD, (1995), Word Investment Report, New York. 
Indeks ten należy definiować jako średnią arytmetyczną z udziałów wielkości majątku przedsiębiorstwa za granicą do całkowitego majątku przedsiębiorstwa (AI), wielkości obrotu za granicą do całkowitego obrotu przedsiębiorstwa (SI) oraz liczby zatrudnionych za granicą do całkowitego zatrudnienia przedsiębiorstwa (EI). W związku z tym wzór kształtowałby się następująco: $\mathrm{TNI}=[\mathrm{AI}+\mathrm{SI}+\mathrm{EI}]: 3$.

Kolejnym sposobem umożliwiającym określenie poziomu umiędzynarodowienia wielowymiarowo jest metoda opracowana przez Sullivan'a. Podstawę tego konceptu tworzy w wersji pierwotnej dziewięć wskaźników (tabela poniżej), które przyporządkowano 3 grupom.

Tabela 2. Wskaźniki internacjonalizacji według Sullivan

\begin{tabular}{|l|l|l|}
\hline \multicolumn{1}{|c|}{ Wskaźnik wydajności } & \multicolumn{1}{|c|}{ Wskaźnik strukturalny } & \multicolumn{1}{|c|}{ Wskaźniki kulturowe } \\
\hline $\begin{array}{l}\text { (1) Obroty za granica jako } \\
\text { procentowy udział wszyst- } \\
\text { kich obrotów }\end{array}$ & $\begin{array}{l}\text { (6) Wartość majątku za } \\
\text { granicą jako procentowy } \\
\text { udział wszystkich majątków } \\
\text { przedsiębiorstwa }\end{array}$ & $\begin{array}{l}\text { (7) Doświadczenie między- } \\
\text { narodowe ścisłego kierow- } \\
\text { nictwa jako udział poświę- } \\
\text { conego czasu zawodowego } \\
\text { za granicą do całkowitego } \\
\text { czasu zawodowego poświę- } \\
\text { conego przedsiębiorstwu } \\
\text { ogółem }\end{array}$ \\
\hline $\begin{array}{l}\text { (2) Aktywność za granicą } \\
\text { jako procentowy udział } \\
\text { wszystkich aktywności } \\
\text { przedsiębiorstwa }\end{array}$ & & $\begin{array}{l}\text { (9) Dystans psychicz- } \\
\text { ny pojmowany poprzez } \\
\text { geograficzne rozproszenie } \\
\text { cześsi międzynarodowych } \\
\text { przedsiębiorstw }\end{array}$ \\
\cline { 1 - 1 } $\begin{array}{l}\text { (3) Czynności marketin- } \\
\text { gowe za granicą jako pro- } \\
\text { centowy udział wszystkich } \\
\text { czynności marketingowych }\end{array}$ & $\begin{array}{l}\text { (7) Liczba zagranicznych } \\
\text { spółek jako procentowy } \\
\text { udział wszystkich spółek }\end{array}$ & \\
\cline { 1 - 1 } $\begin{array}{l}\text { (4) Eksport jako procento- } \\
\text { wy udział całej sprzedaży }\end{array}$ & & \\
\cline { 1 - 1 } $\begin{array}{l}\text { (5) Zyski za granica jako } \\
\text { procentowy udział wszyst- } \\
\text { kich zysków przedsiębior- } \\
\text { stwa }\end{array}$ & & \\
\cline { 1 - 2 } & & \\
\hline
\end{tabular}

Źródło: opracowanie własne na podstawie: Czech-Winkelmann S. (2008), Exportieren, kooperieren oder Direktinvestitionen - alternative Marktstrategien, [w:] Czech-Winkelmann S., Kopsch A. (red.), Handbuch International Business. Strategie, Praxis, Fallbeispiele, Erich Schmidt Verlag, Berlin.

Koncept pomiarowy Sullivan'a dotyczy indeksu skonstruowanego na podstawie 74 przedsiębiorstw, które w czasach pomiaru internacjonalizacji 
należały do najmocniej zinternacjonalizowanych amerykańskich przedsiębiorstw. W opracowaniu tego indeksu wykorzystano jednakże tylko wskaźniki (1), (6), (7), (8) i (9), które zostały zidentyfikowane przez Sullivan'a na podstawie badań statystycznych jako istotne. Sednem tej metody pomiarowej jest stopień internacjonalizacji $\left[\mathrm{DOI}_{\mathrm{INTS}}\right]$, który składa się z sumy wymienionych wyżej pięciu zrównoważonych wartości stosunków liczbowych zmiennych poszczególnych wskaźników. Wzór przedstawia się wówczas następująco:

$$
\mathrm{DOI}_{\mathrm{INTS}}=\mathrm{FSTS}+\mathrm{FATA}+\mathrm{OSTS}+\mathrm{PDIO}+\mathrm{TMIE}^{3}
$$

Stopień internacjonalizacji może przyjmować wartość od [0] (brak umiędzynarodowienia) do [5] (maksymalny stopień umiędzynarodowienia) [Sullivan, 1994, s. 331].

Opracowany przez Sullivan'a koncept pomiarowy internacjonalizacji według Gerstlauer'a ma w sobie zaletę względnej prostoty, a co za tym idzie, łatwość praktycznego zastosowania przy jednoczesnym uwzględnieniu wielu aspektów internacjonalizacji przedsiębiorstwa [Gerstlauer, 2004, s. 80].

Koncept Fisch/Osterle, w przeciwieństwie do wcześniejszych metod, dotyczy pomiaru globalizacji. Pomiar ten dokonywany jest w dwóch płaszczyznach, pierwsza dotyczy geograficznej dystrybucji, druga natomiast różnorodności kulturowej aktywności zagranicznej przedsiębiorstwa.

Dystrybucja geograficzna składa się z zakresu zagranicznych aktywności oraz liczby krajów, w których dane przedsiębiorstwo jest czynne. Przedsiębiorstwo jest tym bardziej zglobalizowane, im częściej podział geograficzny jego aktywności międzynarodowych podobny jest do podziału geograficznego ekonomicznych aktywności na całym świecie. Współczynnik geograficznej dystrybucji gs` może przyjmować wartości $[0,1]$, przy czym wartość [0] przedstawia jedynie krajowe aktywności przedsiębiorstwa, a wartość [1] całkowicie zglobalizowane [Fisch, Oesterle, 2003, s. 7-8]. Na podstawie obrotów za granicą określany jest wskaźnik Gini [g] dla przedsiębiorstwa międzynarodowego (Multinational Company [MNC]). Jako wartość odniesienia służy wskaźnik Gini międzynarodowej

$3 \quad$ FSTS $=$ Foreign Sales to Total Sales (wskaźnik 1), FATA $=$ Foreign Assets to Total Assets (wskaźnik 6), OSTS = Overseas Subsidiaries to Total Subsidiaries (wskaźnik 7), TMIE = Top Managers`International Experience (wskaźnik 8), PDIO = = Psychic Dispersion of International Operations (wskaźnik 9). 
dystrybucji produktu krajowego brutto (Gross National Produkt [GNP]). Współczynnik dystrybucji geograficznej aktywności przedsiębiorstwa [gs`] kształtuje się zatem następująco:

$$
\mathrm{gs}^{\prime}=\frac{1-\mathrm{g}_{\mathrm{MNC}}}{1-\mathrm{g}_{\mathrm{GNP}}}
$$

Wzór 1. Współczynnik dystrybucji geograficznej

Źródło: opracowanie na podstawie: Oesterle M.-J., Laudien S. (2008), Messkonzepte der Internationalisierung, [w:] Czech-Winkelmann S., Kopsch A. (red.), Handbuch International Business. Strategie, Praxis, Fallbeispiel, Erich Schmidt Verlag, Berlin.

Różnorodność kulturowa aktywności zagranicznej przedsiębiorstwa może być wyrażana za pomocą wariancji. Jako punkt odniesienia służy analiza Hofstede [Hofstede, 1980]. Dokonał on pomiaru różnorodności kulturowej 50 krajów i trzech regionów, przyjmując za podstawę trzy wymiary: odległość, indywidualizm a kolektywizm, unikanie niepewności. Do obliczenia różnorodności kulturowej (Curtular Dicersity [Cd']) wykorzystuje się iloraz kulturowej wariancji krajów, w których przedsiębiorstwo posiada spółki zagraniczne $\left[\mathrm{o}^{2} \mathrm{MNC}\right]$ do kulturowej wariancji Hofstede $\left[\mathrm{o}^{2}{ }_{\text {Hofstede }}\right]$. Współczynnik różnorodności kulturowej przyjmuje takie wartości jak w przypadku geograficznej dystrybucji, tzn. mieści się pomiędzy [0-1] [Fisch, Oesterle, 2003, s. 10].

Stopień globalizacji (Degree of Globalization [dog]) to złożona, dodatnia cyfra, składająca się z realnej (geograficzna dystrybucja) oraz wyimaginowanej (różnorodność kulturowa) wartości. Jednostka realnej części wynosi przy tym jeden, natomiast wyimaginowanej to $i=\sqrt{ }-1$.

$$
\operatorname{dog}=\sqrt{g^{2}+\mathrm{cd}^{2}} \cdot \mathrm{e}^{\mathrm{i} \varphi}
$$

Wzór 2. Stopień globalizacji

Źródło: opracowanie na podstawie: Oesterle M.-J., Laudien S. (2008), Messkonzepte der Internationalisierung, [w:] Czech-Winkelmann S., Kopsch A. (red.), Handbuch International Business. Strategie, Praxis, Fallbeispiel, Erich Schmidt Verlag, Berlin.

Wzór ten wyraża pierwiastek kwadratowy stopnia umiędzynarodowienia jako realnej wartości, kąt $\varphi$ określa wpływ różnorodności kulturowej. 
Jeżeli $\varphi$ większy jest niż 45 stopni, wówczas wpływ różnorodności kulturowej jest większy aniżeli wpływ geograficznego rozproszenia. Warto zwrócić uwagę, że zaletą tego konceptu pomiarowego jest fakt, iż w tym przypadku, w porównaniu do tradycyjnych konceptów pomiarowych, dokonuje się sensownych arytmetycznych operacji.

Intensywności internacjonalizacji przedsiębiorstwa nie należy upatrywać wyłącznie w wartościach ekonomicznych. Stopień internacjonalizacji przedsiębiorstw ukazuje się w ich kulturze, stawianych celach, strategii oraz w sposobie zarządzania kierownictwa, a nie tylko w wielkości eksportu czy zagranicznych inwestycjach bezpośrednich. Jednakże ilościowe metody pomiaru internacjonalizacji i globalizacji przedsiębiorstw pozwalają dokładniej odzwierciedlić stopień zaangażowania przedsiębiorstw za granicą.

\section{PODSUMOWANIE}

Internacjonalizacja jako proces umiędzynarodowienia firm, rynków czy instytucji ma charakter dynamiczny i zmierza do globalizacji gospodarki światowej. Dynamika uwarunkowań globalizacji gospodarki światowej w połączeniu z istotą biznesu międzynarodowego pozwala na niezwykle ważne połączenie zagadnień makroekonomicznych z mikroekonomicznymi, zwłaszcza w stosunku do przedsiębiorstw międzynarodowych. Coraz częściej istotnym aspektem staje się wypracowanie metody, dzięki której będzie można określić wskaźnik globalizacji i internacjonalizacji przedsiębiorstw, zarówno z jakościowego, jak i ilościowego punktu widzenia. O ile w literaturze przedmiotu upowszechnione są metody ilościowe umożliwiające pomiar globalizacji i internacjonalizacji przedsiębiorstw, o tyle niewiele jest takich, które w liczbach bezwzględnych przedstawią stopień ich umiędzynarodowienia.

\section{LITERATURA}

Czech-Winkelmann S. (2008), Exportieren, kooperieren oder Direktinvestitionenalternative Marktstrategien, [w:] Czech-Winkelmann S., Kopsch A. (red.), Handbuch International Business. Strategie, Praxis, Fallbeispiele, Erich Schmidt Verlag, Berlin.

Dicken P. (1998), Global shift: transforming the world economy, London. 
Fisch J. H., Oesterle M.-J. (2003), Exploring the Globalization of German MNCs with the Complex Spread and Diversity Measure, "Schmalenbach Business Review", 55, Jg. 1.

Gerstlauer M. (2004), Eignung neuer Informations- und Kommunikationstechnik zur Erhöhung der Internationalität von Forschung und Entwicklung, unveröffentlichte Dissertation, Otto-Friedrichs-Universität.

Glaum M. (1996), Internationalisierung und Unternehmenserfolg, Wiesbaden.

Gołembska E. (2014), Logistyka międzynarodowa, PWN, Warszawa.

Helmig B., Purtschert R., Schauer R., Witt D. (2007), Nonprofit-Organisationen und Märkte, 7. Internationales Colloquium der NPO-Forscher im März 2006 an der Universität Freiburg/Schweiz, DUV Verlag, Wiesbaden.

Kutschker M. (1999a), Das internationale Unternehmen, [w:] Kutschker M. (red.), Perspektiven der internationalen Wirtschaft, Wiesbaden.

Macharzina K. (2003), Grundlagen, [w:] Breuer W., Gürtler M. (red.), Internationales Management: Betriebswirtschaftslehre der internationalen Unternehmung, Wiesbaden.

Nöcker R. (2001), Internationalisierung als Wettbewerbsstrategie, Hamburg.

Oesterle M.-J. (1999), Fiktionen der Internationalisierungsforschung - Stand und Perspektiven einer realitätsorientierten Theoriebildung, [w:] Geringer J. M., Oechsler W. A. (red.), Internationales Management. Auswirkungen globaler Veränderungen auf Wettbewerb, Unternehmensstrategie und Märkte, Wiesbaden.

Oesterle M.-J., Laudien S. (2008), Messkonzepte der Internationalisierung, [w:] Czech-Winkelmann S., Kopsch A. (red.), Handbuch International Business. Strategie, Praxis, Fallbeispiel, Erich Schmidt Verlag, Berlin.

Osiński K. (2010), Biznes międzynarodowy na progu XXI wieku - kompendium, Wydawnictwo Zachodniopomorskiej Szkoły Biznesu w Szczecinie, Szczecin.

Perlitz M., Schrank R. (2013), Internationales Management, 6. Auflage, UVK, Konstanz und München.

Rymarczyk J. (2004), Internacjonalizacja i globalizacja przedsiębiorstw, PWE, Warszawa.

Sullivan D. (1994), Measuring the degree of internationalization of a firm, Journal of International Business Studies, 25. Jg., H. 2.

UNCTAD (1995), Word Investment Report, New York.

Welge M.-K., Holtbrügge D. (2006), Internationales Management. Theorien, Funktionen, Fallstudien, 4. überarbeitete und erweiterte Auflage, SchäfferPoeschel Verlag, Stuttgart. 
Ziółkowska M. (2011), Franczyza w warunkach globalizacji, [w:] Bartkowiak R., Ostaszewski J. (red.), Ekonomia, nauki o zarzadzaniu, finanse i nauki prawne wobec światowych przemian kulturowych, społecznych, gospodarczych i politycznych, Oficyna Wydawnicza SGH, Warszawa.

Żukrowska K. (2001), Polska gospodarka w warunkach globalizacji gospodarki światowej, [w:] Klich J. (red.), Globalizacja, Wydawnictwo Profesjonalnej Szkoły Biznesu, ISS, Kraków.

Zur E., Krystek U. (1997), Internationalisierung als Herausforderung für die Unternehmensführung, [w:] Zur E., Krystek U. (red.), Internationalisierung. Eine Herausforderung für die Unternehmensführung, Springer, Berlin, Heidelberg, New York.

\title{
THE PRIROR METHODS OF MEASUREMENT OF GLOBALIZATION AND INTERNATIOANLIZATION OF COMPANIES
}

\begin{abstract}
Internationalization as a process of globalization of companies, markets and institutions is dynamic and heads towards proliferation of global economy. The dynamics of globalization's conditions of the global economy combined with the essence of international business allows an extremely important combination of microeconomic macroeconomic issues, particularly in relation to international business. Working out the method by which it will be possible to determine indicator of globalization and internationalization companies, both from a qualitative and quantitative point of view becomes an increasingly important aspect. While in the literature of the subject quantitative methods allowing measurement of globalization and internationalization of enterprises are disseminated, there is little on such that present the degree of internationalization in absolute numbers. The purpose of this publication is to present the most important methods of measurement of internationalization and globalization.
\end{abstract}

Keywords: measurement methods; globalization; internationalization of enterprises. 